\title{
Congenital bowing of long bones
}

INSERM

\section{Source}

INSERM. (1999). Orphanet: an online rare disease and orphan drug data base. Congenital bowing of long bones. ORPHA:2292

Long bone bowing is a congenital condition described by the presence of symmetric or asymmetric angular deformity and shortening of the long bones, particularly the femurs, tibiae and ulnae. 